\title{
Structural Trends of Defence Expenditure in the Baltic Countries
}

\section{Gitana DUDZEVIČIŪTE் ${ }^{1}$}

\author{
${ }^{1}$ General Jonas Žemaitis Military Academy of Lithuania, Šilo str. 5A, LT-10322 Vilnius
}

E-mail: ${ }^{1}$ gitana.dudzeviciute@lka.lt

\begin{abstract}
The paper has investigated the patterns of defence expenditure in the Baltic countries, such as Lithuania, Latvia and Estonia during the period of 2004-2018. Distribution of defence expenditure by main category has been analysed and the main tendencies have been provided. The author has done this by applying total expenditure and decomposition approaches. Firstly, the author has calculated the intensity rate of defence expenditure's structural changes in order to assess which country's defence spending structure has been more dynamic over the period analysed. Secondly, FingerKreinin indicator has been used to compare defence expenditure distributions and determine their dissimilarities among the countries under consideration. The author believes that the research highlights key structural trends of defence expenditure and could be helpful for policy makers.
\end{abstract}

KEY WORDS: defence expenditure, structural trends, economic growth, Baltic countries

\section{Introduction}

Defence is controversial, because people have different views about protection, security and threats [1]. Defence output, which is provided in the form of security is military production function with inputs of capital, technology and labour [1]. Defence sector should be investigated as a combination of the human resources, manufacturing, research and development [2]. Most countries tend to spend more on defence because of global insecurity and power politics [3]. The relationship between defence expenditure and economic growth has been examined in a large number of empirical researches $[4,5,6,7,8,9,10,11]$, but the investigations have not showed uniformity among results.

Object of the research: structural changes of defence expenditure in the Baltic countries.

Aim of the research: to perform comparative analysis of the structural changes in defence expenditure in Estonia, Latvia and Lithuania during the period 2004 - 2018.

Limitation of the research: the author has estimated only the distribution of defence expenditure applying decomposition approach. No relationships among the indicators have been calculated. This could be seen as a major limitation of this study, but perhaps a topic for the future research.

The investigation consists of presenting theoretical background, also describing methodology and analysing defence expenditure and its structure in the Baltic countries. Finally, the study is concluded revealing the main findings.

\section{Literature Review}

There has been controversy in the scientific literature over whether defence spending has a positive, negative or no relation impact on economic growth [12]. In examining the relationship between defence and economic growth, it is possible to distinguish 4 types of links as follows: 1) a link showing impact of defence spending on economic development, 2) a link demonstrating influence of economic growth on the level of defence expenditure, 3 ) a feedback between variables analysed and 4) non-existence of any links between anticipated variables [13]. Odehnal and Neubauer (2012) have identified possible links between defence expenditure and economic growth in selected NATO countries from 1950s to 2009 [13]. The research has revealed that economic growth causes defence spending in Germany and Portugal. Moreover, defence expenditure causes economic growth in Belgium, Denmark, France, Germany, Italy, the Netherlands and Portugal [13]. The study of Yilgör et al. (2014) has revealed that in the long term there exists a relationship between defence expenditure and economic growth [12]. The authors have found that defence expenditure is a factor in economic growth. Finally, the research has concluded that defence expenditure in economically developed countries positively contributes to their economic development [12]. Huang et al. (2014) also agree that increasing the share of defence expenditure is favourable for economically strong countries [14]. The study of Duella (2014) has examined the causal relationship between defence spending and economic growth in Algeria for the period 1980-2010. Empirical estimates have indicated that economic growth in the long run is negatively related

\footnotetext{
${ }^{1}$ Corresponding author.

E-mail address: gitana.dudzeviciute@1ka.lt
} 
to defence spending [4]. The examination of the link between the defence expenditure and economic growth has provided different results in the EU countries. Broadly, in economically strong countries, the researchers have detected a bidirectional and unidirectional causality running from defence to economic growth. In economically weaker countries, the causality has appeared to run from economic growth to defence or non-existent [15]. Defence spending has been determined by political, strategic and economic factors [1]. Defence could be as preventative expenditure in case some foreign power starts becoming aggressive [2].

\section{Method of Investigation}

The investigation has been based on NATO information. It has provided a possibility to compare NATO countries by different defence indicators. The research has involved four main steps as follows: 1) descriptive statistics; 2) estimating of intensity rate of structural changes; 3) calculation of the Finger-Kreinin dissimilarity; 4) determination of the relationships between defence expenditure and its categories. All calculations have been made using econometric software Eviews v. 8.0. The intensity rate of structural changes measures the shift of the pattern in time $t_{i}$, compare with the basic period. The higher indicator reveals that one country is more dynamic in structure of defence expenditure than another over the period analysed. The intensity rate has been calculated as follows [16]:

$$
\text { CISC }=\sqrt{\sum_{i=1}^{r}\left(g_{i 1}-g_{i 0}\right)^{2}}
$$

where: $r$ - number of considered defence expenditure by category, gi1, gi0 - the weight of defence expenditure by category $i$ in the analysed period in year 1 and year 0 , respectively.

Finger-Kreinin dissimilarity indicator (D) shows how much a given distribution differs from a chosen. It has been calculated as follows [17]:

$$
D=\frac{1}{2} \sum_{i=1}^{n}\left|a_{i}-b_{i}\right|
$$

where: $a_{i}$ and $b_{i}$ show the share of expenditure by category $i$ in each of the two distributions. D index ranges between zero, denoting equality and one or 100\%, showing maximum dissimilarity.

\section{Investigation Results and Discussion}

\subsection{Descriptive Statistics Results}

During the period 2004-2018, Estonia devoted the largest share of GDP to defence compared to Latvia and Lithuania as well. On average, it amounted to 1.82 percent, while in Latvia and Lithuania it was 1.31 and 1.18 percent respectively. The descriptive statistics has been presented in Table 1 and in the Fig. 1.

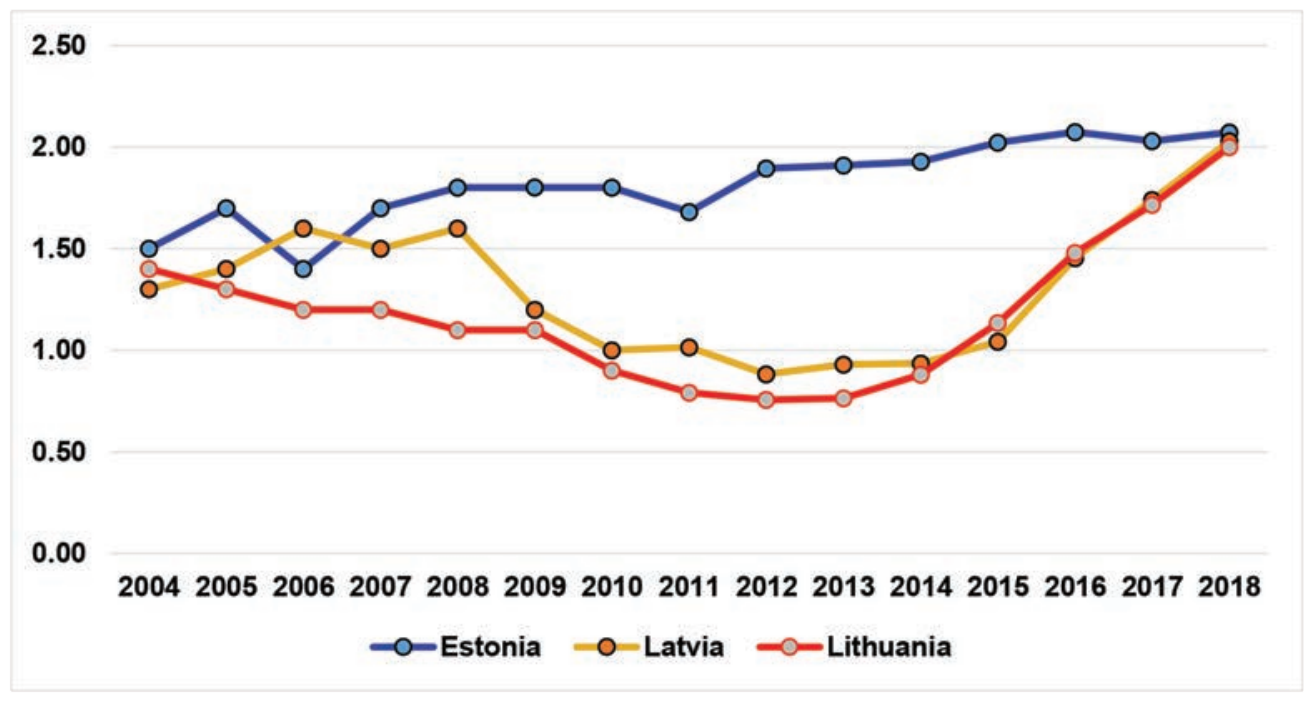

Fig. 1. Defence expenditure as a share of GDP. Source: [18] 
Table 1.

Descriptive statistics

\begin{tabular}{|c|c|c|c|c|c|}
\hline \multirow{2}{*}{$\begin{array}{c}\text { Countries / } \\
\text { statistics }\end{array}$} & \multirow{2}{*}{$\begin{array}{c}\text { Defence as a } \\
\text { share of GDP, } \\
\%\end{array}$} & \multicolumn{4}{|c|}{ Distribution of defence expenditure, $\%$ of total defence expenditure } \\
\hline & & Equipment & Personnel & Infrastructure & Other \\
\hline \multicolumn{6}{|l|}{ ESTONIA } \\
\hline Mean & 1.82 & 15.55 & 33.62 & 12.09 & 38.74 \\
\hline Median & 1.80 & 14.48 & 34.50 & 12.15 & 39.18 \\
\hline Maximum & 2.07 & 23.70 & 39.83 & 16.40 & 47.71 \\
\hline Minimum & 1.40 & 10.10 & 26.00 & 7.98 & 31.03 \\
\hline Std. Dev. & 0.20 & 4.11 & 4.33 & 2.87 & 4.88 \\
\hline \multicolumn{6}{|l|}{ LATVIA } \\
\hline Mean & 1.31 & 12.66 & 47.46 & 10.31 & 29.56 \\
\hline Median & 1.30 & 10.78 & 48.80 & 9.29 & 28.90 \\
\hline Maximum & 2.03 & 35.37 & 59.30 & 17.56 & 38.80 \\
\hline Minimum & 0.88 & 5.40 & 32.06 & 4.16 & 24.25 \\
\hline Std. Dev. & 0.35 & 7.42 & 8.21 & 3.97 & 4.11 \\
\hline \multicolumn{6}{|l|}{ LITHUANIA } \\
\hline Mean & 1.18 & 17.49 & 55.68 & 2.93 & 23.90 \\
\hline Median & 1.35 & 16.20 & 56.30 & 3.20 & 23.67 \\
\hline Maximum & 2.00 & 31.61 & 67.00 & 4.97 & 32.80 \\
\hline Minimum & 0.76 & 9.23 & 40.51 & 1.37 & 20.50 \\
\hline Std. Dev. & 0.36 & 7.73 & 9.10 & 1.03 & 3.21 \\
\hline
\end{tabular}

Source: calculations based on Eviews v. 8.0.

In Estonia, other defence expenditure, including operations and maintenance spending, dominated over the period analysed. In Latvia and Lithuania, expenditure for personnel, including military and civilian spending and pensions, prevailed in the total defence structure. The standard deviation showed that Estonia was more homogeneous than Latvia and Lithuania in terms of defence as a share of GDP and expenditure for equipment and personnel. Lithuania was more homogeneous in the context of expenditure for infrastructure, including NATO common infrastructure and national military construction, as well as other expenditure, including operations and maintenance spending.

Over the period 2004-2014 defence expenditure as a share of GDP dropped from 1.30 to 0.94 percentage in Latvia and from 1.40 to 0.88 percentage in Lithuania. The budgetary motivation for this related to less strategic, geopolitical and terrorism related implications [2]. Meanwhile in Estonia defence spending increased from 1.50 to 1.93 percentage during the same period of time. As a result of growing security threats and conflicts in Ukraine, the European Union countries, Egypt, Libya, Syria and other countries, since 2015, defence spending has started to increase in all three Baltic countries. According to Lilico (2013), in case when foreign power starts becoming aggressive, the country must have available resources to reduce that aggression [2].

\subsection{Intensity Rate of Structural Changes}

The intensity rate of defence structural changes measures the shift of the defence pattern in 2018, compared with 2004. The higher indicator reveals that one of the analysed countries has more dynamic structure of defence expenditure than other countries over the period analysed. As the table below reports, 2018 compared with 2004, Latvia has more dynamic structure of defence expenditure than Estonia and Lithuania (Table 2). 
Intensity rate (percentage points) of defence expenditure's structure, 2018 comparison with 2004

\begin{tabular}{|c|c|c|c|}
\hline Total defence expenditures by category, percentage & Estonia & Latvia & Lithuania \\
\hline Equipment & 4.85 & 27.97 & 18.29 \\
\hline Personnel & 2.75 & 11.74 & 10.59 \\
\hline Infrastructure & 5.72 & 6.65 & 1.17 \\
\hline Other & 3.62 & 9.58 & 8.86 \\
\hline Total & $\mathbf{1 6 . 9 4}$ & $\mathbf{5 5 . 9 4}$ & $\mathbf{3 8 . 9 1}$ \\
\hline
\end{tabular}

Source: author's calculations based on NATO data

This has been mainly due to a significant increase of the defence spending share for equipment and decrease for personnel. The same trends are observed in Lithuania, but the share of equipment expenditure has grown less significantly than in Latvia, although the intensity of changes in personnel spending has been similar in both countries. It has been noted that the situation is different in Estonia, where the structural changes in defense spending have been significantly less intensive than in Latvia and less intensive than in Lithuania. As a result, the intensity of changes in Estonia's defense spending has been more than three times lower than in Latvia and more than twice lower than in Lithuania.

\subsection{Finger-Kreinin Dissimilarity}

To assess the patterns of the defence expenditure dissimilarity across the Baltic countries, Finger-Kreinin has been applied. This indicator has summarized how much a given distribution of defence expenditure differs from other country. Finger-Kreinin ranges between 0 and 100 percent. When value is equal to 0 , this means that the structures of pair of countries being considered are identical; and when it is equal to 100 , this means maximum dissimilarity. Table 3 gives the Finger-Kreinin of defence patterns for all pairings for the 2004 and 2018.

Table 3.

Finger-Kreinin dissimilarity (\%) of the defence expenditure structures

\begin{tabular}{|c|c|c|c|}
\hline Year & Estonia and Latvia & Estonia and Lithuania & Latvia and Lithuania \\
\hline 2004 & 10.40 & 16.60 & 12.20 \\
\hline 2018 & 17.70 & 21.20 & 8.45 \\
\hline
\end{tabular}

Source: author's calculations based on NATO data

Assessing the pairs of the countries, the most significant dissimilarity has been revealed between the defence expenditure structures of Estonia and Lithuania in 2004 and 2018 as well. Dissimilarity has made 16.60 percent in 2004 and 21.20 percent in 2018. Moreover, Finger-Kreinin has suggested that in 2004 Estonia and Latvia had the most similar structures of defence expenditure. In 2018, Latvia and Lithuania were the most similar countries in term of defence expenditure structure. Next section provides the main insights of the investigation.

\section{Conclusions}

The following results of the investigation have been obtained:

- The examination of the link between defence and economic growth has provided different results across the countries. Broadly, in economically strong countries, the researchers have detected a bidirectional and unidirectional causality running from defence to economic growth. In economically weaker countries, the causality has appeared to run from economic growth to defence or non-existent. Defence spending has been determined by political, strategic and economic factors.

- In Estonia, other defence expenditure, including operations and maintenance spending, dominated over the period of 2004-2018. In Latvia and Lithuania, expenditure for personnel, including military and civilian spending and pensions, prevailed in the total defence structure.

- Over the period analysed, Latvia has had more dynamic structure of defence expenditure than Estonia and Lithuania. This has been mainly due to a significant increase of the defence spending share for 
equipment and decrease for personnel. The intensity of changes in Latvia's defense spending has been more than three times higher than in Estonia and 1.5 times higher than in Lithuania.

- The most significant dissimilarity has been revealed between the defence expenditure structures of Estonia and Lithuania in 2004 and 2018 as well. In 2004, Estonia and Latvia had the most similar structures of defence expenditure. In 2018, however, Latvia and Lithuania were the most similar countries in term of defence expenditure structure.

\section{References}

1. Hartley K. The Economics of Defence Policy. A new perspective, 2011. Routledge. London and New York.

2. Lilico A. Why defense spending can help to promote longer - term growth, 2013. http://www.telegraph.co.uk/ finance/comment/10083015/Why-defense-spending-can-help-to-promote-longer-termgrowth.

3. Biswar R K, Kabir E, Rafi Rafat B R. Investment in research and development compared to military expenditure: is research worthwhile? Defence and Peace Economics 2019; 30 (7): 846-857. https://doi.org/10.1080/1024269 4.2018.1477235

4. Duella A. Military burden and economic growth: evidence from a multivariate cointegration analysis. Journal of Global Economics 2014; 2(3), 119. Doi:10.4172/economics.1000119.

5. Chairil T, Sinaga D S, \& Febrianti A I. Relationship between military expenditure and economic growth in ASEAN: evidence from Indonesia. Journal of ASEAN Studies 2013; 1(2): 106-121.

6. Anwar M A, Rafique Z, \& Joiya S A. Defense spending-economic growth nexus: a case study of Pakistan. Pakistan Economicand Social Review 2012; 50 (2):163-182.

7. Khalid M A, Mustapha A B. Long-run relationship and causality tests between military expenditure and economic growth in India. The Economics and Finance Letters 2014; 1(6): 49-58.

8. Hirnissa M T, Baharom A H. Military expenditure and economic growth in Asean-5 countries. Journal of Sustainable Development 2009; 2 (2): 192-202.

9. Atesoglu H S. Defense spending and aggregate output in the United States. Defence and Peace Economics 2009; 20 (1): 21-26.

10. Danek T. Analysis of relationship between military expenditure and economic growth. The Business and Management Review 2013; 3(3): 51-57.

11. Feridun M, Sawhney B, Shahbaz M. The impact of military spending on economic growth: the case of North Cyprus. Defence and Peace Economics 2011; 22 (5): 555-562.

12. Yilgör M, Karagöl E T, Saygili C A. Panel causality analysis between defence expenditure and economic growth in developed countries. Defence and Peace Economics 2014; 25 (2): 193-203. https://doi.org/10.1080/10242694 .2012 .724879

13. Odehnal J, Neubauer J. Causal analysis of economic growth and military expenditure. Recent Advances in Energy, Environment and Economic Development 2012; 233-238.

14. Huang T-Y, Wu P-Ch, and Liu S-Y. Defense-growth causality: considerations of regime-sitching and time- and country-varying effects. Defence and Peace Economics 2017; 28 (5): 568-584. doi: 10.1080/10242694.2016.1202002.

15. Topcu M, Aras I. Defense spending and economic growth: extended empirical analysis of the European Union countries. Defense and Peace Economics 2015; 26 (2): 233-246.

16. Pavelescu F M. Methodological considerations on the size of coefficient of intensity of structural changes (CISC). Romanian Statistical Review 2014; 2: 95-107.

17. Memedovic O, Iapadre L. Structural change in the world economy: main features and trends. United Nations Industrial Development Organization, Vienna International Centre, Research and Statistics Branch, Working Paper 24/2009; 2010.

18. NATO data. https://www.nato.int/cps/en/natohq/news_164482.htm. 